Int. J. Morphol.,

29(2):318-324, 2011

\title{
Anatomical Study on the Descent of Testis in Prenatal Goat (Capra hircus)
}

\author{
Estudio Anatómico del Descenso Testicular Prenatal en la Cabra (Capra hircus)
}

\author{
M. M. Farooqui, Chandrapal, Archana \& Ajay Prakash
}

FAROOQUI, M. M. CHANDRAPAL, ARCHANA \& PRAKASH, A. Anatomical study on the descent of testis in prenatal goat (Capra hircus). Int. J. Morphol., 29(2):318-324, 2011.

SUMMARY: A study was conducted on 70 embryo/ foetii of goats to observe the descent of testis. These foetii were grouped into I (0-30 days), II (31-60 days), III (61-90 days), IV (91-120days) and V (121 days up to term, having 14 embryos/ foetii in each group. The genital ridge was observed at $1.2 \mathrm{~cm}$ CRL ( 23 day) on the ventromedial aspect of mesonephros. At $42^{\text {nd }}$ day, the genital ridge developed into cylindrical structure, the testis, located in the middle of metanephros. The abdominal migration was completed upto $88^{\text {th }}$ day. The testes were situated in the inguinal canal from $89^{\text {th }}$ to $95^{\text {th }}$ day. From $90^{\text {th }}$ day onward, scrotal migration had been observed, however the testis did not reach the base of the scrotum up to term. During the descent of testis, a peritoneal fold detached from the caudal end of the gonad and extended up-to the abdominal floor on $42^{\text {nd }}$ day, known as gubernaculum. In the initial stages of pregnancy it was thin, whitish, jelly like. On $70^{\text {th }}$ day it was enveloped by processus vaginalis. In group V, it became hardened, longer and cord like.

KEY WORDS: Anatomy; Testis; Gubernaculum; Goat.

\section{INTRODUCTION}

The descent of the testis from the genital ridge in foetal to an extracorporeal location after birth is a mandatory developmental process to ensure that the mature testis promote normal spermatogenesis. The human testis is descended generally at birth, in conjunction with the rabbit, pig and horse. By contrast, cattle and deer have fully descended testis in early gestation whereas it is delayed after birth in dog (Hughes \& Acerini, 2008). The gubernaculum testis seems to be the most important structure involved in testicular migration. The role of gubernaculum in testicular migration is especially due to its ability to dilate and shorten, thus facilitating the testis course through the inguinal canal (El Zoghbi et al., 2007). A study was conducted on goat fetuses to record the course of descent of testis and the development of gubernaculum in goat.

\section{MATERIAL AND METHOD}

A study was conducted on the 70 embryo/ foeti ranged from 23 days to full term collected from the gravid uteri of apparently healthy goat, obtained from local abattoir. Each foetus was measured for its crown rump length in centimeters with the help of nylon tape (Harvey 1959) and weighed in grams on analytical balance. The approximate age was computed according to the formula derived by Singh et al. (1979) after interpolation of the formula given by Hugget \& Widdas (1951) in mammals. These embryo/foeti were divided into five groups (Table I).

The sex of foeti was determined by the appearance of genital tubercle in the form of epithelial tag, genital swelling, anogenital raphae up-to mid stage of II group. In other groups the sex was identified by the development of penis and scrotal sac. The foeti were dissected by giving ventral abdominal incision to observe the development of testis. The topographic location and shape of testis were recorded.

The testis along with the gubernaculums was collected and the tissues were processed by routine paraffine embedding technique and were sectioned at 5-6 $\mu$. The sections were stained with H\& E for general fibroarchitecture (Luna, 1968), Mallory's triple stain (Crossman, 1937) for collagen fibers, Wilder's reticulin stain (Luna) for reticular fibers, Weigert's Resorcin Fuchsinstain (Luna) for elastic fibers demonstration.

Pt. Deen Dayal Upadhyaya Veterinary University-Mathura, India. 
Table I. Division of groups according to age and weight of fetuses used in the study.

\begin{tabular}{clcc}
\hline $\mathbf{n}$ & Group & Age & Weight of foetus (g) \\
\hline 1 & Group-I & $0-30$ days & -- \\
2 & Group-II & $31-60$ days & 0.86 to 18.9 \\
3 & Group- II I & $61-90$ days & 56 to 200.0 \\
4 & Group- IV & $91-120$ days & 284 to 435.8 \\
5 & Group- V & 121-till term & 675 to 1720.34 \\
\hline
\end{tabular}

\section{RESULTS AND DISCUSSION}

At 23rd day (1.2cm CRL), the genital ridge appeared as an aggregation of cells on the ventromedial aspect of mesonephros extending from the 2 nd thoracic segment to the last sacral vertebra (Fig.1). It was completely covered by the developing stomach and sex of embryo could not be identified. Singh et al. also observed the genital ridge on 23 days in goat embryos extending from 5-12 body segments. Erickson (1966) and Noden \& de Lahunta (1985) observed the genital ridge on $32^{\text {nd }}$ and $28^{\text {th }}$ days, respectively in bovines. The early occurrence of genital ridge in present study might be due to the fact that the goat has smaller gestation period than that of bovines. The regression of cranial part of mesonephros on $30^{\text {th }}$ day pushed the gonads close to metanephros, therefore at $30^{\text {th }}$ day of gestation the genital ridge became swollen and was located in the middle of the mesonephros. It was confined to the developing lumbar vertebrae. The left gonad was related ventromedially with the stomach, while the right one was related to the coils of intestine. This was in close association with the observations of Gier \& Marion (1970) who observed the genital ridge on $28^{\text {th }}$ day of gestation in embryos of ox.

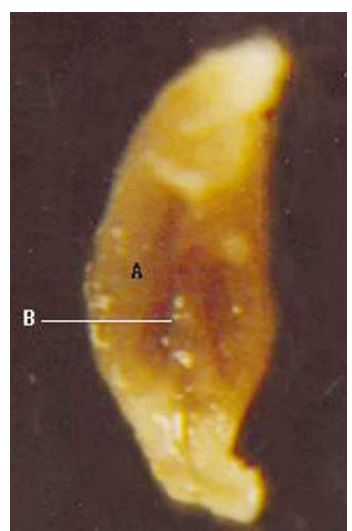

Fig. 1. Photograph of mesonephros of $1.2 \mathrm{~cm} \mathrm{CRL}$ goat embryo (23 days) showing mesonephros (A) and genital ridge (B).
On $42^{\text {nd }}$ day (II group) of gestation the genital ridge developed into a cylindrical structure, the testis with rounded extremities, situated in the middle of the ventromedial aspect of the mesonephros (Fig. 2). These were related with the coils of intestine. On $48^{\text {th }}$ day, the testis became oblong and shifted to the cranial pole of mesoneophros, related ventrolaterally to the metanephros. The left testis was related with the coils of intestine ventromedially and medially with the future colon. The right one was related with the

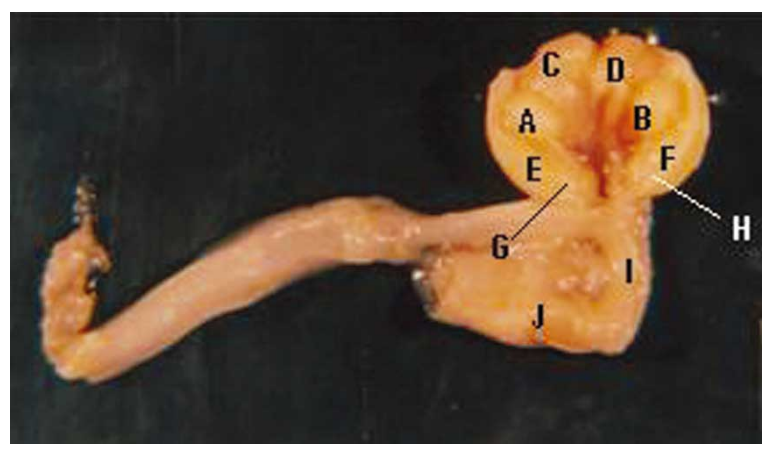

Fig. 2. Photograph of a male genitalia of 44 day old goat foetus showing right testis (A), left testis (B), right metanephros (C), left metanephros (D), right mesonephros (E), left mesonephros $(\mathrm{F})$, right mesonephric duct $(\mathrm{G})$, left mesonephric duct $(\mathrm{H})$, pelvic urethra (I) and developing penis (J).

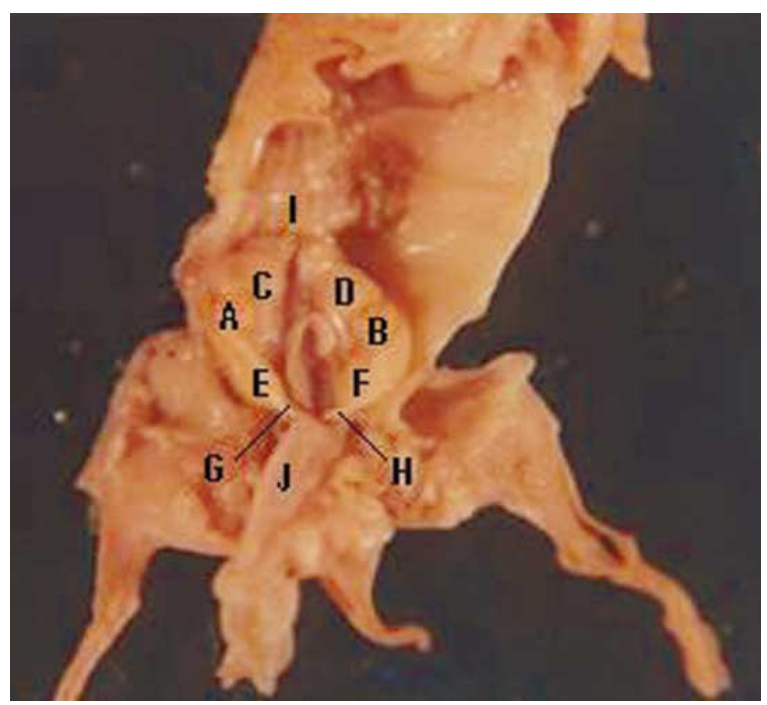

Fig. 3. Photograph of a 52 day old goat foetus showing right testis (A), left testis (B), right metanephros (C), left metanephros (D), right mesonephros (E), left mesonephros (F), right mesonephric duct $(\mathrm{G})$, left mesonephric duct $(\mathrm{H})$, liver (I) and urinary bladder (J). 


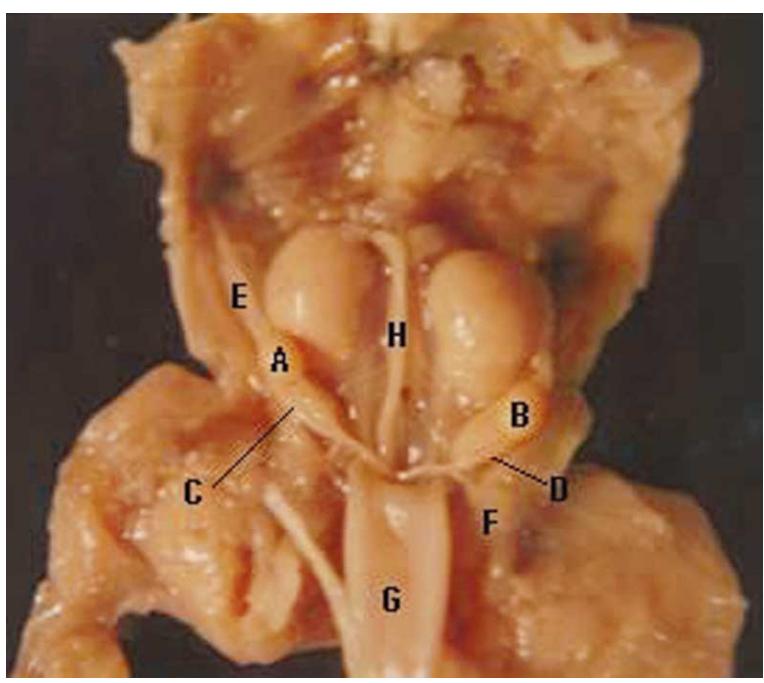

Fig. 4. Photograph of a 57 day old goat foetus showing right testis (A), left testis (B), right mesonephric duct (C), left mesonephric duct entering into urethra (D), diaphragmatic ligament of mesonephros (E), gubernaculum (inguinal ligament) $(\mathrm{F})$, urinary bladder $(\mathrm{G})$ and segment of large intestine $(\mathrm{H})$.

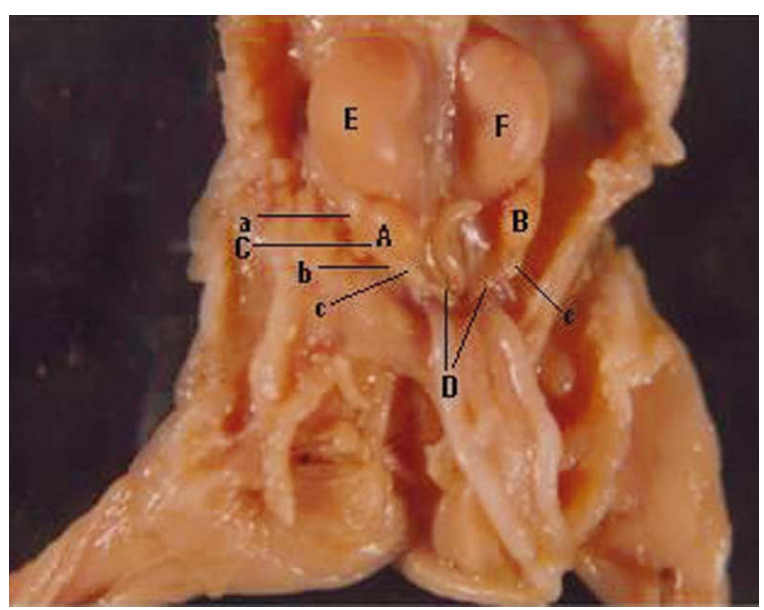

Fig. 5. Photograph of a 60 day old goat foetus showing right testis (A), left testis (B) reached near the caudal pole of respective metanephros, right epididymis $(C)$, containing head (a), body (b), tail (c), right and left vas deferens (D), right metanephros (E) and left metanephros (F).

lobe of liver. At this stage the lateral and medial surfaces of the testis were convex. The attached border was convex while free border was straight. On $52^{\text {nd }}$ day, the testes were oval to oblong in shape and placed in the middle of the ventrolateral aspect of respective metanephros (Fig. 3). The medial and lateral surfaces were convex and the latter was attached to the mesonephric duct and mesonephros. The testes further descended down on $55^{\text {th }}$ and $57^{\text {th }}$ day (Fig. 4) and on $60^{\text {th }}$ day reached near the caudal pole of metanephros (Fig. 5). Similar observations were made by Gier \& Marion in mammals. Each testis presented rounded extremities and a relatively large caput epididymis was observed lateral to the proximal extremity of testis. Singh (1970) also observed relatively larger and heavier epididymis as compared to the corresponding testis in eleven months of camel foetus.

In third group (61-90 days) each testis descended more towards the inguinal ring as reported by Baishya \& Vyas (1991) in Surti buffalo foeti. They further described that the descent of testis in caudal direction towards the further inguinal canal was due to the growth of the body and enlargement of adjacent organs. At $65^{\text {th }}$ day of gestation, the testes were elongated in shape and were slightly away from the caudal pole of the respective metanephros. The left testis was present slightly at a lower level than the right one and was related with the coils of the small intestine while the right one was related with the dorsal lobe of liver (Fig. 6). The lateral surface of both the testes was slightly convex while the medial one was relatively flat. The proximal extremity was rounded and narrower than the distal one, which was related to the cauda epididymis. On $78^{\text {th }}$ day the testes were $6.0-6.2 \mathrm{~cm}$ away from the caudal pole of metanephros in between the metanephros and internal inguinal ring. These were related ventromedially with the coils of intestine. The whitish, jelly like gubernaculum was attached to the distal extremity of the testis ensheathed by peritoneal fold, processus vaginalis which pierce the inguinal canal (Fig.7). On $88^{\text {th }}$ day the testes were just at the rim of the internal inguinal ring and the cauda epididymis entered the inguinal canal along with the peritoneal covering, the tunica vaginalis. Medially the testes were related with umbilical arteries. On $89^{\text {th }}$ day the testis finally entered the inguinal canal along with the tunica vaginalis. This observation was in agreement with the reports of Gier \& Marion.

In group IV (91-120 days) the testes started descending towards the scrotal sac. They were situated in the inguinal canal from $89^{\text {th }}$ to $95^{\text {th }}$ day of gestation. At $96^{\text {th }}$ day of gestation the testis were observed at the external inguinal ring (Fig. 8). Morphologically, the lateral surface of testes was more convex than the medial one. The anterior border was convex where as the caudal border was flat and attached with the corpus epididymis. The proximal extremity was covered with the head of epididymis anterolaterally. At this stage, the testis, epididymis, vas deferens, testicular artery, vein, nerves and lymphatics were in common sheath of tunica vaginalis. The gubernaculum testis started from the distal extremity of testis up-to the scrotal sac. At $98^{\text {th }}$ day of gestation, the testes reached just above the neck of the scrotum and further descended down to the middle of the scrotum at $106^{\text {th }}$ day after crossing the neck on 101st day of gestation.

In group V (121day till term), each testes were morphologically similar to the testes as described in group IV 


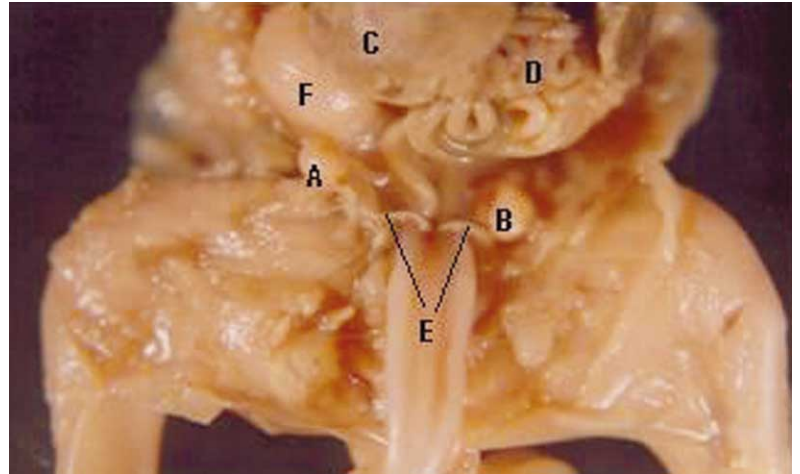

Fig. 6. Photograph of a 68 day old goat foetus showing right testis (A) located away from caudal pole of metanephros, left testis (B) at lower level than right, dorsal lobe of liver (C), coils of intestine (pushed upward) (D), right and left vas deferens (E) and metanephros (F).

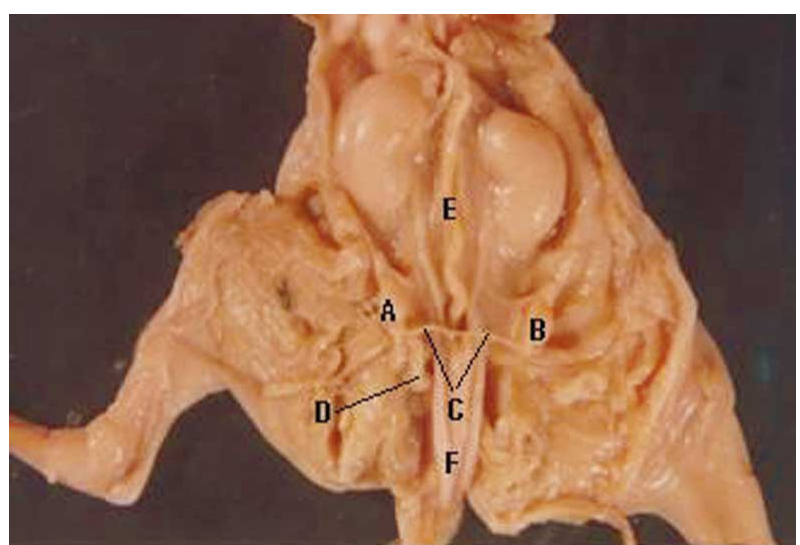

Fig. 7. Photograph of a 78 day old goat foetus showing right testis (A) and left testis (B) situated mid way between metanephros and internal inguinal ring, right and left vas deferens (C), gubernaculum (D), a segment of large intestine (E) and urinary bladder $(\mathrm{F})$.

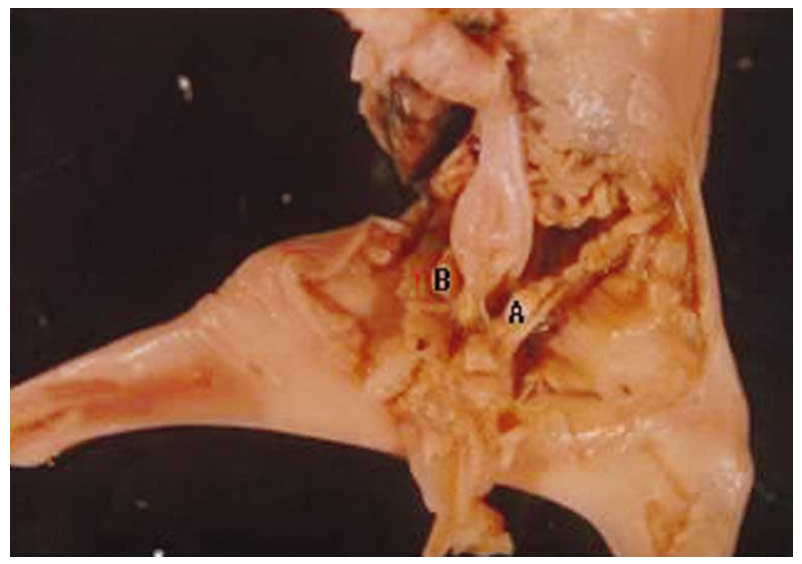

Fig. 8. Photograph of a 88 day old goat foetus showing left testis at the rim of internal inguinal ring and cauda entered in the inguinal canal (A) and right testis (B).

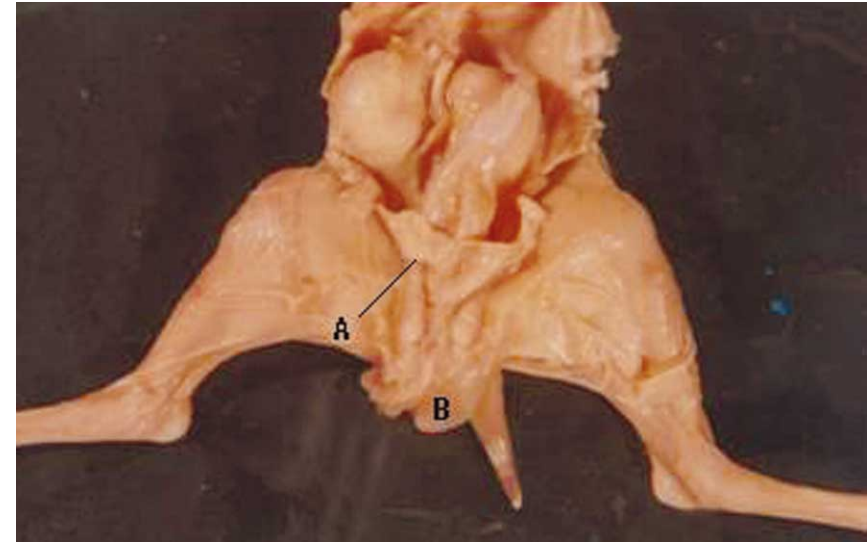

Fig. 9. Photograph of a 96 day old goat foetus showing right and left testis crossed the external inguinal ring (A) and scrotum (B).

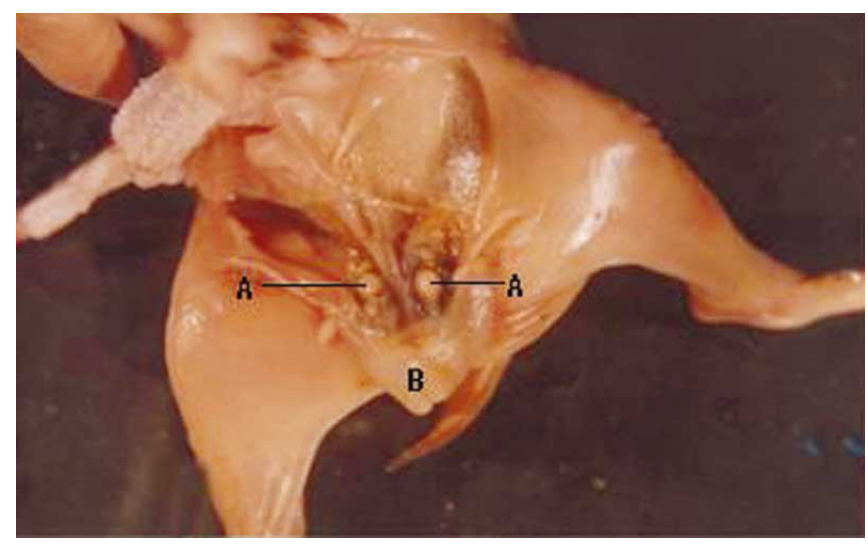

Fig. 10. Photograph of a 106 day old goat foetus showing testis situated in middle of the scrotum (pulled upward to see the location) (A) and scrotum (B).

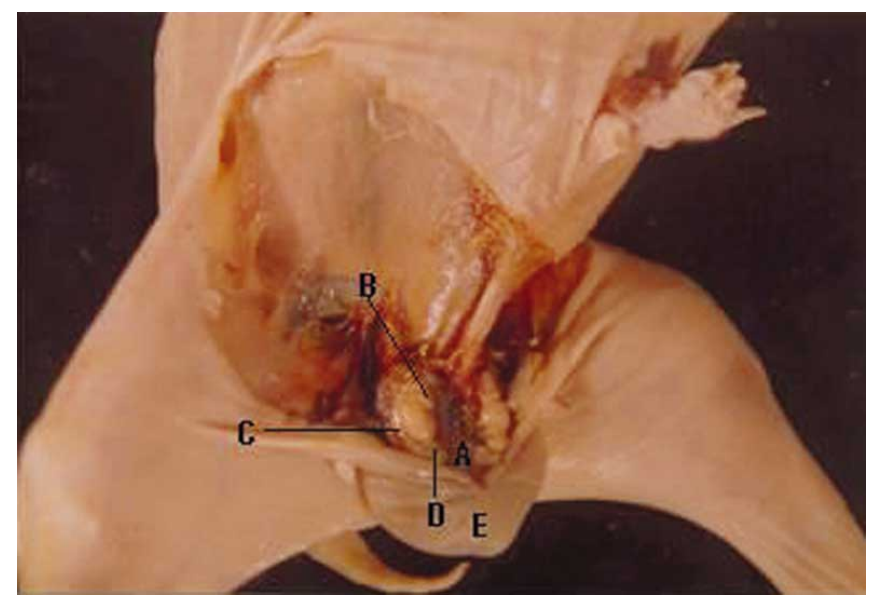

Fig. 11. Photograph of a 123 day old goat foetus showing (after removal of the tunica vaginalis) right and left testis with epididymis in the middle of the scrotum (A), head (B), body (C), tail of the epididymis (D) and scrotum (E). 


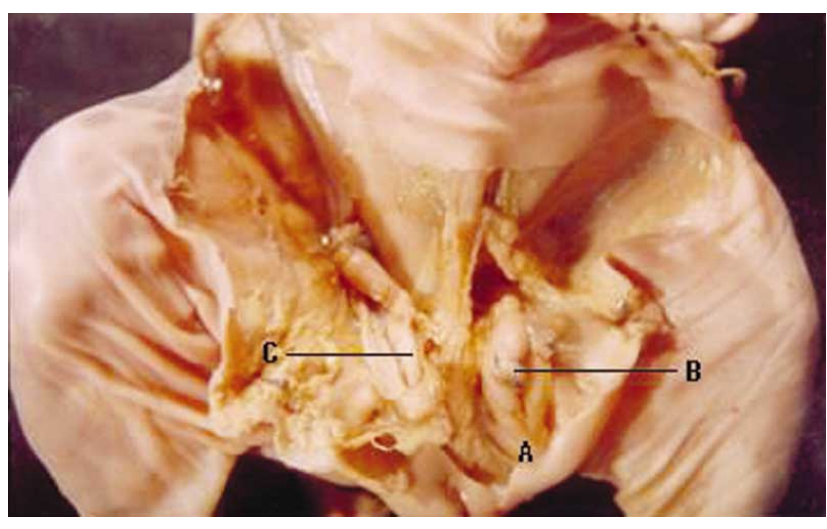

Fig. 12. Photograph of a 137 day old goat foetus showing (after incising the scrotum and tunica vaginalis) testes reached towards the distal part of scrotum (A), tail of epididymis (B), and gubernaculum testis/ epididymal ligament (C).

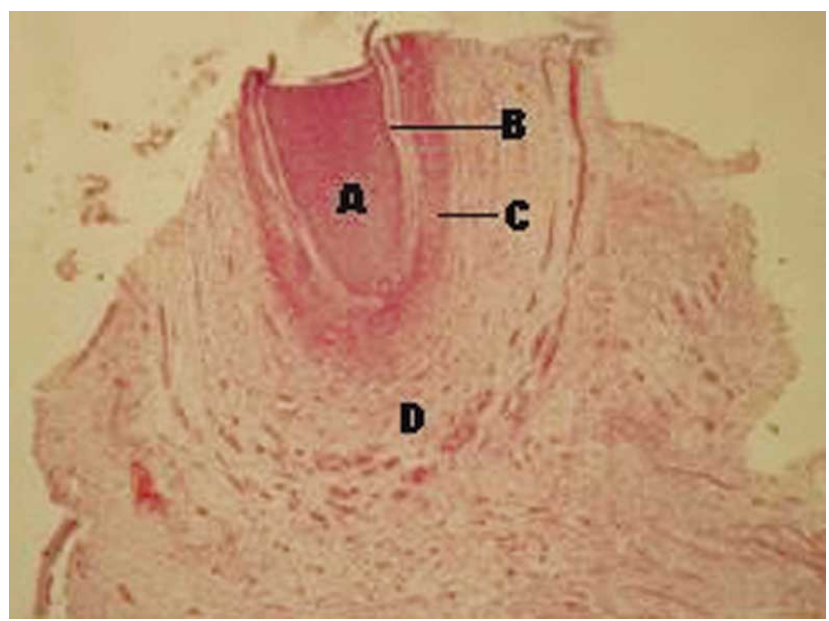

Fig. 13. Photomicrograph of gubernaculums from a 66 day old goat foetus showing plica gubernaculum (A), surface epithelium (B), cremaster muscle (C), loose mesenchyma with isolated developing muscle bundle (D). H\&E X 40

and covered by tunica vaginalis, fascia and skin. Up-to $137^{\text {th }}$ day of gestation they remained in the middle of the scrotum and slightly downwards at 144th day but did not reach the distal part of the scrotum (Fig. 9). Gier \& Marion reported that the testes passed the inguinal ring in the foetal sheep at about 80 days, in bull at 100th -105 th days, in pig at $100^{\text {th }}$ $-110^{\text {th }}$ day and in horse at about 10 months. They settled down in the scrotum at 140 days in foetal bull. In the present study, the testes started inguinal migration from $89^{\text {th }}$ day onwards which was completed on $96^{\text {th }}$ day. However, they did not reach the distal end of the scrotum up to parturition. This finding was contrary to the earlier reports of Arthur (1964) who observed descent of testis into the scrotum in sheep between 2.5-3 months though the gestation period of two species is the same. The scrotal migration started at $101^{\text {st }}$ day, which was in contrast to the earlier reports of Ramkumar et al. (1988) who mentioned that this process started at 90 days in goat foetus. Bissa et al. (1988) also reported that the testes had not descended in the scrotum in Bikaneri camel calves even at birth. Baishya \& Vyas observed that the testes reached the scrotal sac at $213^{\text {th }}$ day gestation in Surti buffalo.

Gubernaculum testis. On $42^{\text {nd }}$ day of gestation, two peritoneal folds detached from either ends of gonads. The cranial one was attached to the metanephros; mesonephros and the abdominal wall while the caudal fold crossed the distal end of mesonephros ran towards the abdominal floor. The cranial and caudal folds were referred as the diaphragmatic and the inguinal ligaments, respectively. The inguinal ligament was thin, whitish, jelly like structure, which became thick on $60^{\text {th }}$ day of gestation (Fig. 4). It ran downward and backward towards the future inguinal canal. Patten (1948) reported similar views during the process of descent of testis in swine. However, the author did not mention the age of the foeti. The change in texture of inguinal ligament from thin lamina to thick band was in close association with the earlier reports of Wensing (1968). The inguinal ligament was whitish and had soft semisolid consistency and gelatinous in fixed specimens. Backhouse \& Butler (1960) reported similar views in pig embryos/ foeti ranging in size from $6 \mathrm{~mm}$ to $350 \mathrm{~mm}$ CRL. In group III (61 to 90 days) at $78^{\text {th }}$ day, the gubernaculum was enveloped by peritoneal covering, processus vaginalis and about $89^{\text {th }}$ day it entered the inguinal canal. In IV group (91 to 120 days) its lower end reached scrotal sac at $96^{\text {th }}$ day of gestation. Thereafter it was completely present in the scrotum. In V group (121 days to up to term) the gubernaculum became harder and longer as compared to IV group (Fig.12).

Microscopically, at $56^{\text {th }}$ day of gestations the gubernaculum appeared as solid mass of mesenchymal cells. Backhouse \& Butler described this structure as plica gubernaculi, whereas Wensing reported as mesenchymal mass. The cytoplasm of mesenchymal cells was highly eosinophilic. The nuclei were spherical or ovoid in shape. Their nuclear chromatin was concentrated towards nuclear membrane. However, few cells contained darkly stained nuclei. Few of the mesenchymal cells were arranged in circular manner and they enclosed a space leading the development of future capillaries.

In between the mesenchymal cells few fine reticular fibres were observed in the periphery of plica gubernaculi particularly towards caudal pole. At $66^{\text {th }}$ day of gestation, the gubernaculum in addition to above structures, contained more number of blood capillaries (Fig. 10). 
At $85^{\text {th }}$ day of gestation, a loosely arranged mesenchymal tissue replaced the plica gubernaculum with an enhanced vascularity. The reticular fibres became coarser with the advancement of age.

At $108^{\text {th }}$ day of gestation, the plica gubernaculi comprised of loosely arranged cellular texture with an abundance of adipose tissue giving an appearance resembling fascia.

At this stage, near the caudal end of plica gubernaculi, the mesenchymal tissue, covering epithelium and muscle cremaster internus confluenced together was forming a common mass. Numerous reticular and few collagenous fibres dispersing in various directions were observed at the caudal end of gubernaculum. Occasionally nerve endings were also encountered in this zone. At $116^{\text {th }}$ day onwards, plica gubernaculi contained more loosely arranged cellular texture.
A layer of simple squamous epithelium surrounded the plica gubernaculi in all stages of gestation during this study. Cytoplasm of these cells was eosinophilic and flat nuclei were darkly stained. Wensing reported that the epithelium covering the gubernaculum was located in the abdominal and extra abdominal parts. This epithelium has been termed as mesothelium (Backhouse \& Butler).

In the initial stages of gestation densely arranged smooth muscle bundles cremaster internus were running parallel and surrounding the plica gubernaculi with the advancement of gestation these bundles separated away from each other appeared as isolated fibres on $108^{\text {th }}$ day and onwards.

The cremaster internus muscle was surrounded by very loose mesenchymal mass, which contained few differentiating isolated muscle bundles. The nuclei of these cells either placed centrally or towards periphery giving the appearance of skeletal muscle. However, striations were not distinguishable.

FAROOQUI, M. M. CHANDRAPAL, ARCHANA \& PRAKASH, A. Estudio anatómico del descenso testicular prenatal en la cabra (Capra hircus). Int. J. Morphol., 29(2):318-324, 2011

RESUMEN: Para observar el descenso de los testículos se realizó un estudio en 70 embriones/fetos de cabra. Estos fetos se agruparon en 5 grupos: I (0-30 días), II (31-60 días), III (61-90 días), IV (91 120 días) y V (121 días hasta término, con 14 embriones / fetos en cada grupo. La cresta genital se observó a 1,2cm CRL (23 días) en la cara ventromedial del mesonefros. En el día 42 día, la cresta genital se convirtió en estructura cilíndrica y los testículos se encontraban en el centro del metanefros. La migración abdominal se completó en 88 días. Los testículos están situados en el canal inguinal entre los 89 y 95 días. Del día 90 en adelante, se observó la migración escrotal, sin embargo, el testículo no llegó a la base del escroto hasta el término del desarrollo. Durante el descenso de los testículos, a los 42 días, un pliegue peritoneal (gubernaculum testis) separado del extremo caudal de la gónada, se extendió hacia el suelo-abdominal. En las etapas iniciales de la preñez la gónada era delgada, blanquecina, gelatinosa. En el día 70 el testículo fue envuelto por el proceso vaginal. En el grupo V, el testículo se había endurecido y alargado asemejándose a una cuerda.

PALABRAS CLAVE: Anatomía; Testículo; Gubernaculum testis; Cabra.

\section{REFERENCES}

Arthur, G.H. Wright's Veterinary Obstetrics. $3^{\text {rd }}$ ed., Baltimore, Williams \& Wilkins Co., 1964. pp. 475.

Backhouse, K. M. \& Butler, H. The gubernaculum testis of the pig (Sus scropha). J. Anat., 94:107-20, 1960.

Baishya, G. \& Vyas, K. N. Studies on foetal testicular development in Surti buffalo (Bubalus bubalis). Indian Vet. J., 68(6):556-60, 1991.

Bissa, U. K.; Rai, A. K. \& Khanna, N. D. Testicular descent and development of scrotum in camel calves - Bikaneri breed. Indian J. Anim. Sci., 58(10):1200-1, 1988.

Crossman, G.A. A modification of Mallory's connective tissue stain with discussion of principles involved. Anat. Record, 69:33-8. 1937.

El Zoghbi, C. S.; Favorito, L. A.; Costa, W. S.; Sampaio, F. J. B. Structural analysis of gubernaculum testis in cryptorchid patients submitted to treatment with human chorionic gonadotrophin. Int. Braz. J. Urol., 33(2)223-30, 2007.

Erickson, B.H. Development and radio-response of the prenatal bovine ovary. J. Reprod. Fertil., 10:97-105, 1966.

Gier, H. T. \& Marion, G. B. Development of mammalian testis. In : The testis. Johnson, A. J.; Gomes, W. R. \& Vandemark, N. L. (Eds.). New York, Academic Press, 1970. pp.2-43. 
FAROOQUI, M. M. CHANDRAPAL, ARCHANA \& PRAKASH, A. Anatomical study on the descent of testis in prenatal goat (Capra hircus). Int. J. Morphol., 29(2):318-324, 2011.

Harvey, E. B. Aging and foetal development. In: Reproduction in Domestic Animals. Cole, H. H. \& Eupps, P. T. (Eds.). 1st Ed. New York, Academic Press Inc., 1959. pp.461-6.

Hugget, A. St. G. \& Widdas, W.F. The relationship between mammalian foetal weight and conception age. J. Physiol, 114:306-17, 1951.

Hughes, I. A. \& Acerini, C. L. Factors controlling testis descent. Eur. J. Endocrinol., 59(1):S75-82, 2008.

Luna, L. G. Manual of Histological staining methods of the armed Forces Institute of Pathology. $3^{\text {rd }}$ ed. New York, McGraw Hill Book Comp., 1968. pp 38, 80, 87, 145.

Noden, D. M. \& de Lahunta, A. The Embryology of Domestic Animals. $1^{\text {st }}$ Ed. Baltimore, The Williams and Wilkins Company, 1985. pp.322-340.

Patten, B. M. Embryology of the Pig. New York, McGraw Hill Book Company, 1948. pp. 211.

Ram Kumar; Sharma, A. K. \& Prasad, M.C. Morphometric study of caprine foetus. Indian J. Anim. Sci., 58(8):92831,1988 .

Singh, U. B. Gross, histological and certain histochemical observation on the testis and poll gland of camel (Camelus dromadarius) during different phases of sexual cycle. Ph.D. thesis, University of Udaipur, Udaipur, 1970.

Singh, Y.; Sharma, D. N. \& Dhingra, L. D. Morphogenesis of the testis in goat. Indian Journal of Animal Sciences, 49(11):925-31, 1979.

Wensing, C. J. G. Reproductive Pathology of Domestic Mammals. New York, Academic Press, 1968. p. 4.
Correspondence to:

M. M. Farooqui,

Pt. Deen Dayal Upadhyaya Veterinary University-

Mathura

INDIA

Email: pathak_arcvik@yahoo.com

Received: 26-08-2010

Accepted: 19-11-2010 